\title{
Influence of epididymal maturation on the capacity of hamster and rabbit spermatozoa for complement activation
}

\author{
S. S. Witkin*, J. M. Richards* and J. M. Bedford* $†$ \\ Departments of * Obstetrics and Gynecology and $\uparrow$ Cell Biology and Anatomy, Cornell University \\ Medical College, New York, New York 10021, U.S.A.
}

\begin{abstract}
Summary. Hamster and rabbit spermatozoa released from the epididymis were tested for the ability to activate complement via the alternative pathway. While hamster spermatozoa were more active, the spermatozoa of both species reduced complement activity in homologous and also human serum previously adsorbed to remove sperm antibodies, and they bound $\mathrm{C} 3$ in the presence of EGTA $+\mathrm{Mg}^{2+}$. Hamster spermatozoa from the caput epididymidis were more anticomplementary and bound more $\mathrm{C} 3$ than did cauda spermatozoa and, though less marked, a similar difference was evident between caput and cauda spermatozoa from the rabbit epididymis.
\end{abstract}

\section{Introduction}

Internal fertilization has been adopted independently by several different vertebrate groups, but in none is there a clear picture of the complications that insemination may raise for the female, nor of the factors involved in the response to semen within the female tract. The report that bull spermatozoa activate complement via the alternative pathway (Clark \& Klebanoff, 1976) suggests a non-immunogenic mechanism that may be one means of sperm removal by the female. Although the extent to which complement components occur throughout the female tract is uncertain (Oliphant, Randall \& Cabot, 1977; Schumacher, 1980), haemolytic complement has been detected in cervical secretions (Price \& Boettcher, 1979). Furthermore, antibody-coated ova evoke a rapid directed leucocytosis in the oviduct, probably as a consequence of $\mathrm{C} 5 \mathrm{a}$ formation, implying the potential for activation of the classical complement pathway at that site (unpublished results). It is also possible that some aspect of change in the sperm surface in the epididymis influences the recognition of and response to spermatozoa by the female tract. We have examined directly the ability of spermatozoa of the rabbit and hamster to activate complement via the alternative pathway, and the effect of epididymal maturation on it.

\section{Materials and Methods}

Spermatozoa and serum. Epididymal spermatozoa were obtained from sexually mature male hamsters and rabbits. Human, hamster and rabbit sera containing $0.01 \mathrm{M}$-EDTA were admixed with spermatozoa from the caput or cauda epididymidis $\left(3.5 \times 10^{7} / \mathrm{ml}\right)$ and incubated for $60 \mathrm{~min}$ at $0^{\circ} \mathrm{C}$ to remove antibodies reactive with spermatozoa. The spermatozoa were then removed by centrifugation and an equal volume of a solution containing $0.02 \mathrm{M}-\mathrm{CaCl}_{2}$ and $0.005 \mathrm{M}-\mathrm{MgCl}_{2}$ was added. The treated sera were stored in aliquants at $-20^{\circ} \mathrm{C}$ until used. In pilot experiments, it was 
established that results with sera subjected to 2 or more absorptions did not differ from those obtained with sera absorbed only once.

Haemolytic complement activity. Haemolytic complement activity of absorbed sera in the presence or absence of spermatozoa was determined by the method of Palmer (1980). Briefly, absorbed sera were diluted $1: 15$ in barbitone buffer with or without $6 \times 10^{5}$ spermatozoa $(0.3 \mathrm{ml}$ final vol.) and incubated at $37^{\circ} \mathrm{C}$ for $60 \mathrm{~min}$. The spermatozoa were then removed by centrifugation and the sera serially diluted in barbitone buffer in wells of a round-bottom microfilter plate $(0.2$ $\mathrm{ml} /$ well). Antibody-coated sheep erythrocytes $\left(2.5 \times 10^{6} / 0.05 \mathrm{ml}\right)$ were then added and incubated for $60 \mathrm{~min}$ in a water bath at $37^{\circ} \mathrm{C}$. The cells were then pelleted by centrifugation and $0.1 \mathrm{ml}$ samples were transferred to a new microtitre plate for measurement of cell lysis by determination of the absorbance at $414 \mathrm{~nm}$. Total haemolytic complement activity $\left(\mathrm{CH}_{50}\right)$ was calculated as described by Palmer (1980).

C3 binding to spermatozoa. The deposition of $\mathrm{C} 3$ from serum onto a cell surface is an indication of complement activation (Pangburn \& Muller-Eberhardt, 1978). This was determined here for spermatozoa by an enzyme-linked immunosorbent assay (ELISA). Fresh epididymal spermatozoa, intact as determined by Trypan Blue exclusion $\left(5 \times 10^{4} /\right.$ well for rabbit or $5 \times 10^{3} /$ well for hamster), were fixed to wells of a microtiter plate with $0.5 \%$ glutaraldehyde (Witkin, Shahani, Gupta, Good \& Day, 1980). The lower concentration of the larger hamster spermatozoa was found to be optimal for their binding to the wells. The fixed spermatozoa were washed three times with PBS containing $0.05 \%$ Tween 20 (PBS-Tween) before use. Absorbed human serum was diluted $1: 4$ in PBS-Tween containing $10 \mathrm{~mm}$ EGTA, $2 \mathrm{mM}-\mathrm{MgCl}_{2}$. EGTA chelates $\mathrm{Ca}^{2+}$ in the serum, thereby blocking antibody-mediated (classical pathway) complement activation (Aguado, Perrin, Ramirez, Miescher \& Lambert, 1980). The addition of $\mathrm{Mg}^{2+}$ permitted only direct (alternative pathway) complement activation by spermatozoa. The sera $(0 \cdot 1 \mathrm{ml})$ were added to the top row of a microtitre plate and serially diluted with PBS-Tween down the plate. The plate was then incubated in a $37^{\circ} \mathrm{C}$ bath for $90 \mathrm{~min}$, washed three times with PBS-Tween and each well incubated with $0 \cdot 1 \mathrm{ml}$ of a $1: 200$ dilution in PBS-Tween of alkaline phosphatase-conjugated pig IgG antibody to human C3 (Medical Technology Corp., Hackensack, NJ). Following an additional $90 \mathrm{~min}$ at $37^{\circ} \mathrm{C}$, the wells were again washed three times in PBS-Tween and C3 on the sperm surface was quantitated by the addition of $p$-nitrophenyl phosphate and determination of the absorbance at $405 \mathrm{~nm}$ (Witkin $e t$ al., 1980). C3 was detected with goat IgG antibody to rabbit C3 (Cappel Labs., Cochranville, PA) when rabbit serum was used, followed by alkaline phosphatase-conjugated rabbit IgG antibody to goat IgG (Litton Bionetics, Kensington, MD).

\section{Results}

Effect of epididymal spermatozoa on haemolytic complement activity. Human serum was incubated with spermatozoa from the hamster caput, corpus or cauda epididymidis in 4 separate experiments, and residual haemolytic complement activity was measured (Table 1). Caput spermatozoa were clearly best able and cauda spermatozoa were least able to reduce the haemolytic activity of absorbed human serum. Similar results were obtained regardless of whether the serum had been absorbed previously with cauda or caput spermatozoa, or when cauda-absorbed hamster serum was substituted for human serum.

Similarly, rabbit spermatozoa were incubated in human serum previously absorbed with rabbit cauda epididymal spermatozoa, and haemolytic complement activity was determined in two separate experiments (Table 1). Caput spermatozoa reduced complement activity to the greatest extent, while corpus and cauda spermatozoa of the rabbit were much less effective. Rabbit caput spermatozoa were not as anticomplementary as were hamster caput spermatozoa for human serum on a per cell basis. This may have been due, at least in part, to the larger size of hamster spermatozoa. 
Table 1. Effect of spermatozoa from different regions of the epididymis on total haemolytic complement activity $\left(\mathrm{CH}_{50}\right)$

\begin{tabular}{llc}
\hline Species* & Region & Mean $\mathrm{CH}_{50}$ (standard deviation) \\
\hline Blank & - & 100 \\
Hamster & Caput & $<10$ \\
& Corpus & $31(24)$ \\
& Cauda & $69(13)$ \\
Rabbit & Caput & $61(19)$ \\
& Corpus & $93(5)$ \\
& Cauda & $103(6)$ \\
\hline
\end{tabular}

Human sera, preadsorbed with hamster or rabbit cauda spermatozoa, were incubated with the various epididymal sperm populations and residual $\mathrm{CH}_{50}$ was determined.

* 4 animals for hamster, 2 for rabbit.

Table 2. C3 binding to spermatozoa from different regions of the epididymis

\begin{tabular}{lll}
\hline Species* $^{*}$ & Region & Mean absorbance (standard deviation) \\
\hline Hamster & Caput & 1.0 \\
& Corpus & $0.51(0 \cdot 18)$ \\
& Cauda & $0.27(0 \cdot 09)$ \\
Rabbit & Caput & 1.0 \\
& Corpus & $0.63(0 \cdot 14)$ \\
& Cauda & $0.60(0.23)$ \\
\hline
\end{tabular}

Human sera, preadsorbed with hamster or rabbit cauda spermatozoa, were incubated with the various epididymal spermatozoa and $\mathrm{C} 3$ binding was measured by ELISA. The values for $\mathrm{C} 3$ binding to caput spermatozoa were normalized to an absorbance at 405 nm of 1.0 .

* 4 animals for each species.

C3 binding to epididymal spermatozoa. To confirm that hamster caput spermatozoa activate complement to a greater extent than do corpus and cauda spermatozoa, the quantity of $\mathrm{C} 3$ deposited on the surface after incubation in serum was measured in 4 separate experiments by ELISA (Table 2). Addition of EGTA and $\mathrm{Mg}^{2+}$ to the serum before admixture with the spermatozoa ensured that direct (alternative pathway) complement activation by spermatozoa, and not antibody-mediated activation, was responsible for the $\mathrm{C} 3$ deposition. Caput spermatozoa bound the most $\mathrm{C} 3$, corpus spermatozoa an intermediate amount, and cauda spermatozoa bound the least amount of $\mathrm{C} 3$ at the cell surface.

Human and rabbit sera previously absorbed against rabbit cauda spermatozoa were also incubated with rabbit spermatozoa from the successive regions of the epididymis, and C3 binding was determined in 4 experiments. As with hamster spermatozoa, rabbit caput spermatozoa always bound more $\mathrm{C} 3$ than did corpus and cauda spermatozoa (Table 2), and this decrease in binding of C3 to the sperm surface with maturation was qualitatively unaffected by chelation of $\mathrm{Ca}^{2+}$.

\section{Discussion}

It has been proposed that immunoglobulin binds to spermatozoa in the epididymis (Suarez, Hinton \& Oliphant, 1981) and that this association eventually results in classical pathway complement 
activation in the female tract, thereby initiating the acrosome reaction (Suarez \& Oliphant, 1982). It is highly unlikely that sperm-induced complement activation serves this function. Antibodycoated spermatozoa are generally unable to traverse cervical mucus (Jager et al., 1981) or avoid complement-mediated immune destruction (Bronson, Cooper \& Rosenfeld, 1982) in the cervix or uterus. In addition, living spermatozoa can undergo the acrosome reaction in a defined medium in vitro (Rogers, 1978) in the absence of complement, and in complement-depleted females in vivo (Bedford \& Witkin, 1983). Regardless of whether immunoglobulin may be associated with epididymal spermatozoa, our results confirm for hamster and rabbit the discovery by Clark \& Klebanoff (1976) that bull spermatozoa directly activate complement via the alternative pathway without the participation of specific antibody. The level of that ability is not a fixed characteristic, but diminishes as a function of epididymal maturation. That complement depletion permits more spermatozoa to populate the upper reaches of the reproductive tract in the rabbit, in which insemination is vaginal (Bedford \& Witkin, 1983), points to this ability as one possible element for their fate in the female. As it appears now, the plasmalemma of the mature spermatozoon would have the least tendency to activate complement and so may have a selective advantage in avoiding immune destruction.

Which intrinsic constituents of the sperm surface activate complement are not known. It is likely, however, that the diminished ability for complement activation reflects some aspect of epididymal surface change (Moore, 1981; Feuchter, Vernon \& Eddy, 1981). It is tempting to consider sialic acid groups as being important, since these moieties minimise the tendency of certain other cells to activate complement via the alternative pathway (Fearon, 1978). However, the status of sialic acid in relation to epididymal maturation surface changes is presently unclear (Holt, 1980; Toowicharanont \& Chulavatnatol, 1983). It is possible that, according to species, other terminal side chains of sperm surface glycoproteins, as well as $n$-acetyl neuraminic acid, may specifically diminish the ability of the sperm surface to activate complement.

This work was supported by NIH grants HD-16586 and HD-15528. We thank Ann Marie Bongiovanni and Shelley Kramer for excellent technical assistance.

\section{References}

Aguado, M.T., Perrin, L.H., Ramirez, R., Miescher, P.A. \& Lambert, P.H. (1982) Evaluation of alternative pathway and factor $\mathbf{B}$ hemolytic activities in patients with systemic lupus erythematosus: correlations with the alternative pathway regulatory proteins. Clin. exp. Immunol. 42, 495-505.

Bedford, J.M. \& Witkin, S.S. (1983) Influence of complement depletion on sperm function in the female rabbit. J. Reprod. Fert. 69, 523-528.

Bronson, R.A., Cooper, G.W. \& Rosenfeld, D.L. (1982) Correlation between regional specificity of antisperm antibodies to the spermatozoon surface and complement-mediated sperm immobilization. Am. J. Reprod. Immunol. 2, 222-224.

Clark, R.A. \& Klebanofi, S.J. (1976) Generation of neutrophil chemotactic agent by spermatozoa : role of complement and regulation by seminal plasma factors. J. Immun. 117, 1378-1386.

Fearon, D.T. (1978) Regulation by membrane sialic acid of $\mathrm{H}$-dependent decay dissociation of amplification C 3 convertase of the alternative complement pathway. Proc. natn. Acad. Sci. U.S.A. 75, 1971-1975.

Feuchter, F.A., Vernon, R.B. \& Eddy, E.M. (1981) Analysis of the sperm surface with monoclonal antibodies: topographically restricted antigens appearing in the epididymis. Biol. Reprod. 24, 1099 1110.

Holt, W.V. (1980) Surface-bound sialic acid on ram and bull spermatozoa: deposition during epididymal transit and stability during washing. Biol. Reprod. 23, $847-857$.

Jager, S., Kremer, J., Kuiken, J., van SlachterenDraaisma, T., Mulder, J. \& de Wilde-Janssen, I.W. (1981) Induction of the shaking phenomenon by pretreatment of spermatozoa with sera containing antispermatozoal antibodies. Fert. Steril. 36, 784-791.

Moore, H.D.M. (1981) Glycoprotein secretions of the epididymis in the rabbit and hamster: localization on epididymal spermatozoa and the effect of specific antibodies on fertilization in vivo. J. exp. Zool. 215 , 77-85.

Oliphant, G., Randall, P. \& Cabot, C.L. (1977) Immunological components of rabbit fallopian tube fluid. Biol. Reprod. 16, 463-469.

Palmer, D.F. (1980) Complement fixation test. In Manual of Clinical Immunology, 2nd edn, pp. 35-47. Eds N. R. Rose \& H. Friedman. Am. Soc. Microbiol., Washington, D.C. 
Pangburn, M.K. \& Muller-Eberhardt, H.J. (1978) Complement $\mathrm{C} 3$ convertase: cell surface restriction of $\mathrm{H}$ control and generation of restriction on neuraminidase-treated cells. Proc. natn. Acad. Sci. U.S.A. 75, 2416-2420.

Price, R.J. \& Boettcher, B. (1979) The presence of complement in human cervical mucus and its possible relevance to infertility in women with complement-dependent sperm-immobilizing antibodies. Fert. Steril. 32, 61-66.

Rogers, B.J. (1978) Mammalian sperm capacitation and fertilization in vitro: a critique of methodology. Gamete Res. 1, 165-223.

Schumacher, G.F.B. (1980) Humoral immune factors in the female reproductive tract and their changes during the cycle. In Immunological Aspects of Infertility and Fertility Regulation, pp. 93-142. Eds D. S. Dhindsa \& G. F. B. Schumacher. Elsevier/North Holland, New York.
Suarez, S.S. \& Oliphant, G. (1982) Interaction of rabbit spermatozoa and serum complement components. Biol. Reprod. 27, 473-483.

Suarez, S.S., Hinton, B.T. \& Oliphant, G. (1981) Binding of a marker for immunoglobulins to the surface of rabbit testicular, epididymal and ejaculated spermatozoa. Biol. Reprod. 25, 1091-1097.

Toowicharanont, P. \& Chulavatnatol, M. (1983) Direct assay of bound sialic acid on rat spermatozoa from the caput and cauda epididymidis. J. Reprod. Fert. 67, 275-280.

Witkin, S.S., Shahani, S.K., Gupta, S., Good, R.A. \& Day, N.K. (1980) Demonstration of IgG Fc receptors on spermatozoa and their utilization for the detection of circulating immune complexes in human serum. Clin. exp. Immunol. 44, 441-452.

Received 18 February 1983 